\title{
INTERACTIVE CHEMISTRY TEACHING MATERIAL BASED ON AUGMENTED REALITY TECHNOLOGY IN COVALENT BONDING SUBMATERIAL \\ Aflah Farchan Rizqullah ${ }^{1}$, Achmad Lutfi ${ }^{2}$ \\ ${ }^{12}$ Program Studi Pendidikan Kimia, FMIPA Universitas Negeri Surabaya. Jalan Ketintang, Kel, Ketintang, Kec. Gayungan, Kota Surabaya, Jawa Timur 60231, Indonesia. \\ * Corresponding Author. E-mail: achmadlutfi@unesa.ac.id
}

Received: 22 Januari 2021

Accepted: 22 Mei 2021

Published: 28 Mei 2021

doi: $10.29303 /$ cep.v4i1.2441

\begin{abstract}
This study aimed to obtain the feasibility of interactive teaching materials based on augmented reality technology in covalent bonding in terms of validity, practicality, and effectiveness. The research design uses the 4D model, which is limited to the third stage, namely Define, Design, and Develop. Feasibility is based on validation, practicality, and effectiveness. Based on the validation results on content validation and construct validation, the percentage of $82.66 \%$ and $85.55 \%$ was obtained as very valid criteria. Practicality was obtained from students' responses and observations with a percentage of 95.5\% and $98.61 \%$ on practical criteria. Effectiveness is obtained from learning outcomes with the acquisition of N-Gain 0.75 in the high category and paired t-test with a sign of $0.000<0.05$ so that there is a significant difference between the pretest score and the posttest score. The results of students' motivation obtained a percentage of $79.34 \%$ in the effective category. It proves that the teaching material is suitable for use as a learning medium. In the future, it is hoped that this augmented reality technology can be further developed in other chemical materials so that it can make learning more interactive.
\end{abstract}

Keyword: Augmented Reality, Covalent Bonding, Teaching Material.

\section{BAHAN AJAR KIMIA INTERAKTIF BERBASIS TEKNOLOGI AUGMENTED REALITY PADA SUBMATERI IKATAN KOVALEN}

\begin{abstract}
Abstrak
Tujuan dari penelitian ini untuk memperoleh kelayakan bahan ajar interaktif berbasis teknologi augmented reality pada submateri ikatan kovalen ditinjau dari kevalidan, kepraktisan, dan keefektifan. Desain penelitian menggunakan model 4D yang dibatasi hingga tahap ketiga, yaitu Define, Design, dan Delevop. Kelayakan didasarkan pada validasi, kepraktisan, dan keefektifan. Berdasarkan hasil validasi pada validasi isi dan validasi konstruk diperoleh persentase $82,66 \%$ dan $85,55 \%$ masuk kriteria sangat valid. Kepraktisan diperoleh dari hasil respon dan observasi peserta didik dengan persentase 95,5\% dan 98,61\% pada kriteria praktis. Keefektifan diperoleh dari hasil belajar dengan perolehan N-Gain 0,75 pada kategori high dan uji t berpasangan dengan sign 0,000 $<0,05$ sehingga terdapat perbedaan yang signifikan antara skor pretest dengan skor posttest. Hasil motivasi peserta didik diperoleh persentase 79,34 \% pada kategori efektif. Hal ini membuktikan bahwa bahan ajar layak digunakan sebagai media pembelajaran. Kedepannya diharapkan teknologi augmented reality ini dapat dikembangkan lebih lanjut pada materi kimia lainnya sehingga dapat membuat pembelajaran lebih interaktif.
\end{abstract}

Kata kunci: Augmented Reality, Bahan Ajar, Ikatan Kovalen 


\section{INTRODUCTION}

Chemistry is studying the structure, properties, and changes of matter and energy that attend to material changes (Depdiknas, 2006). According to Nopihargu (2014), chemical phenomena are divided into three levels of representation, there is macroscopic, submicroscopic, and symbolic level. The macroscopic level contains representations of phenomena that can be directly observed. The submicroscopic level contains particles' representations in chemical phenomena, such as electrons, molecules, and atoms, and the symbolic level contains symbolic representations, picture signs, chemical Equations, and chemistry calculation. Three of them are related in their application to the learning process.

In practice, chemistry learning is limited to the level of macroscopic and symbolic representations. It makes the submicroscopic level learned by students individually and hoped that they could integrate their understanding by looking at the illustrations from books. Students' difficult experiences will certainly have an impact on understanding the abstract chemical materials to get the concrete facts and materials (Nopihargu, 2014). The difficulty in understanding abstract chemistry materials occurs because students cannot directly witness the materials of material, such as the process of chemical bonding. In fact, understanding the chemical bond material is a support for the next chemical materials (Ilyasa, 2020).

Chemical bonding material describes atoms' process forms any bonds, whether with the same or different atoms. A chemical bond occurs because a group of atoms shows a more stable unity. After all, it has a lower energy level than the atoms' energy level that comprise it in a separate state (Effendy, 2013). The materials in chemical bonding are abstract, so it difficult to study contextually. A good understanding of the materials given will make it easier for students to understand chemical bonding material (Widarti et al., 2018).

The pre-research results were conducted on 35 students of XI grade at SMAN 13 Surabaya on chemical bonding material, $54.3 \%$ of students had difficulty understanding learning in covalent bond sub materials. The effective implementation of online learning also strengthens it is only $37.1 \%$. It makes it $68.6 \%$ of students difficult to understand the material presented by the teacher. In addition, the teacher center learning method is still dominantly applied in the learning process with a percentage of $62.9 \%$.

In the school learning process, textbooks used to achieve the learning objectives also have miss material on students' potential. In the high school phase, their mental development develops from concrete to abstract during this period (Sirakaya and Cakmak, 2018). For this reason, teaching material is needed to help teachers and students understand the abstract materials by a concrete illustration. Thus, the student's potential can be maximally developed, and the learning process becomes effective and efficient.

According to Prastowo (2012), teaching materials are all materials (both information, tools, and text) that are systematically arranged and contain the unity of competencies that students will understand. In addition, teaching materials must be able to achieve the planning objectives and reviewing the implementation of the learning process. Teaching materials need to be supported by learning media, so the material's message can be received well and understood by students. The use of technology integrated with learning media will provide meaningful learning and attract students' attention by following the learning process (Sirakaya and Cakmak, 2018).

According to (Andayani and Junaidi, 2018), the use of technology in chemistry learning also plays a role in increasing student motivation. With interactive learning, it is hoped that can provide an external stimulus to the learning process, increasing student learning motivation, which will certainly have an impact on student learning outcomes (Lutfi, 2013).

Learning media has the aim of facilitating communication in the learning process. Learning media must be support by the learning material so that the students can understand it easily and the teacher's message can be conveyed well (Yuliono et al., 2018). One interactive technology that can be applied in learning media and supports the use of teaching materials to support three levels of chemical representation is augmented reality technology.

Augmented Reality is a technology that combines virtual objects in two or three dimensions into a real environment. The virtual 
object will be projected in realtime, so it looks real. These objects contain information as labels or virtual objects that can only be seen with a smartphone camera or computer. The augmented reality system works by analyzing in realtime to displaying objects captured by the camera (Rifa'i et al., 2014). With this technology, abtract chemical material like covalent bonds can be ilustrated in real trems, so that students can understand them properly.

The camera, which is considered an "eye" in AR technology, takes an image from a marker containing virtual object information continuously, processes it then produces virtual interactions that appear in the real world. Combining the virtual and real-world can make the learning process more effective and efficient (Kamelia, 2015).

During the COVID-19 pandemic, the learning process is only done through online learning using online class and video conference platform. So, it is very limited to get interactive teaching-learning between students and teachers. According to Ilyasa (2020), the learning process that combines conventional and online systems, usually known as blended learning, can influence students' perceptions of learning activities.

In the application, the blended learning model can combine the learning process from various physical and virtual sources. This model can be applied to effectively adjust the conditions agreed by teachers and students (Sandi, 2012). Thus, the use of augmented reality as media can help students get a better understanding of chemical bonding material than conventional learning.

Based on the description above, it is necessary to have interactive teaching materials based on Augmented Reality technology in covalent bonding materials. And until now, such teaching materials are not yet available, so it needs to be developed. And the purpose of this study is to obtain appropriate interactive teaching materials based on Augmented Reality technology on covalent bonding sub materials.

\section{RESEARCH METHOD}

The research model used is a 4D development model, which is limited to the development phase. This 4D model's phases include the Define, Design, Develop, and Disseminate phases (Ibrahim, 2014).

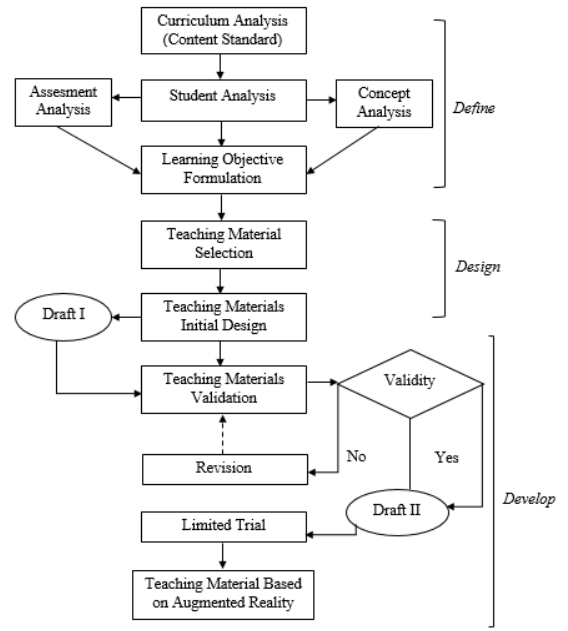

Picture 1. 4D Development Model Adaptation

To measure the feasibility of the teaching materials to be developed according to (Plomp and Nieveen, 2010) research design in terms of the results of its validity, practicality, and effectiveness.

This study's data collection techniques were obtained from validation sheets, learning outcomes from pretest-posttest, and questionnaire sheets that consist of response, motivation, and student observations.

\section{a. Validity Data Analysis}

The data analysis technique of validation results obtained from two chemistry lecturers and one chemistry teacher is based on the Likert scale, as shown in Table 1.

Table 1. Likert Scale

\begin{tabular}{cc}
\hline Assessment & Scale Value \\
\hline Very Bad & 1 \\
Bad & 2 \\
Enough & 3 \\
Good & 4 \\
Very Good & 5 \\
\hline
\end{tabular}

(Riduwan, 2015)

Furthermore, the percentage calculated using the Likert scale data is calculated using the following Equation 1.

Equation 1. Likert Scale Calculation

Percentage $(\%)=\frac{\varepsilon \text { Data collection score }}{\text { Criteria score }} \times 100 \%$

The percentage results from the validation phase are then interpreted in Table 2. 
Table 2. Validation Result Score Interpretation

\begin{tabular}{cl}
\hline Percentage (\%) & \multicolumn{1}{c}{ Category } \\
\hline $0-20$ & Very Invalid \\
$21-40$ & Invalid \\
$41-60$ & Enough \\
$61-80$ & Valid \\
$81-100$ & Very Valid \\
\hline & \multicolumn{1}{c}{ (Riduwan, 2015) }
\end{tabular}

Based on these criteria, the development of teaching materials in this study is feasible from the validity aspect if the percentage is $\geq 61 \%$.

\section{b. Practically Data Analysis}

The observation questionnaire instrument and the responses of students are for obtaining the practicality assessment. The data analysis technique of the two instruments is based on the Guttman Scale in Table 5.

Table 5. Guttman Scale

\begin{tabular}{cc}
\hline Answer & Value \\
\hline Yes & 1 \\
No & 0 \\
\hline
\end{tabular}

Then the percentage data calculated using the Guttman Scale is calculated using the following Equation 5.

Equation 5. Likert Scale Calculation

Percentage $(\%)=\frac{\varepsilon \text { Data collection score }}{\text { Criteria score }} \times 100 \%$

The percentage results from the practicality phase are then interpreted in Table 6 below.

Table 6. Practicality Score Interpretation

\begin{tabular}{cl}
\hline Percentage (\%) & \multicolumn{1}{c}{ Category } \\
\hline $0-20$ & Very Impractical \\
$21-40$ & Impractical \\
$41-60$ & Enough \\
$61-80$ & Practical \\
$81-100$ & Very Practical \\
\hline
\end{tabular}

(Riduwan, 2015)

Based on these criteria, the development of teaching materials in this study is considered feasible in terms of practicality, the percentage criteria are $\geq 61 \%$

\section{c. Effectiveness Data Analysis}

The development phase then continued with a limited trial in the online classroom to determine the teaching materials' effectiveness and practicality. This research was conducted at SMA Negeri 13 Surabaya. The target is 20 students of the XI IPA class in Januari 2021 with uses blended learning method.

Assessment of effectiveness is obtained from learning outcomes and student motivation questionnaires. Learning outcomes are obtained with the one group pretest-postest design system with the following Equation 2.

\section{Equation 2. One Group Pretest-Postest $\mathrm{O}_{1} \mathrm{X} \mathrm{O}_{2}$}

Explanation :

$\mathrm{O}_{1}$ : Pretest implementation before using teaching materials

$\mathrm{X}$ : Treatment (Use of teaching materials)

$\mathrm{O}_{2}$ : Postest implementation before using teaching materials

Student learning outcomes can be said to be complete if the minimum score of 75 is obtained. Here's the formula used to calculate the value of the learning outcome:

Equation 3. Learning Outcome Score

Score $=\sum$ True Answers x 10

(The pretest-posttest conduct by 10 questions)

Learning outcomes are stated to increase if the $n$ gain value is based on Equation 4 and interpreted by Table 3 .

Equation 4. $N$-Gain Value

$N$-Gain $=\frac{\text { Spostest }- \text { Spretest }}{\text { Smax }- \text { Spretest }} \times 100 \%$

Table 3. N-Gain Interpretation Value

\begin{tabular}{ll}
\hline Value & Criteria \\
\hline $\mathrm{G} \geq 0,7$ & High \\
$0,3 \leq \mathrm{G}<0,7$ & Medium \\
$\mathrm{G}<0,3$ & Low \\
\hline
\end{tabular}

(Hake, 1999)

Based on these criteria, the development of teaching materials in this study is feasible in terms of effectiveness if it reaches the "medium" or "high" criteria. Furthermore, to determine the difference between the average pretest and posttest scores, a Paired T-test was carried out with a significance level of 5\% after testing the normality value with Shapiro-Wilk.

Based on data collection, if a significant difference is obtained from the pretest and 
posttest results, the teaching materials developed can be declared effective.

Meanwhile, the student motivation questionnaire analysis is based on a Likert scale modified as Table 4.

Table 4. Likert Scale of Motivation

\begin{tabular}{ccc}
\hline \multirow{2}{*}{ Assessment } & \multicolumn{2}{c}{ Score Value } \\
\cline { 2 - 3 } & $\begin{array}{c}\text { Positive } \\
\text { Statement }\end{array}$ & $\begin{array}{c}\text { Negative } \\
\text { Statement }\end{array}$ \\
\hline Totally Disagree & 1 & 5 \\
Disagree & 2 & 4 \\
Doubtful & 3 & 3 \\
Agree & 4 & 2 \\
Totally Agree & 5 & 1 \\
\hline
\end{tabular}

Then calculate the percentage to interpreted it according to Riduwan (2015) Score Interpretation to determine the effective value of teaching materials.

\section{RESULT AND EXPLANATION}

This the research data that has been carried out and described in each phase analysis of the research. The obtaining process results and analysis have carried out based on the 4D model, which is limited to $3 \mathrm{D}$, as follows:

\section{Define Phase}

The defining phase is the preparation phase in the development of teaching materials through four steps that are arranged systematically to synthesize the learning objective.

\section{a. Front-End Analysis}

This analysis aims to find the existing problems. The problem has been obtained from data collection by literature studies and field studies through field observations and questionnaires. Consideration in this analysis is the curriculum that applies in school.

The curriculum that used in SMA Negeri 13 Surabaya is the 2013 revised curriculum, in this curriculum, the students are facilitated to explore their knowledge by uses developing information technology to support the learning activities.

\section{b. Learner Analysis}

This analysis aims to determine students' characteristics by taking attention to the characteristics, abilities, and learning experiences of students. The general age terms of students in SMA/MA is 15-18 years old. According to Jean Piaget, at this stage, humans have entered intellectual development. From the social, economic background obtained from the preresearch results in October 2020, it was found that each individual has a smartphone to support their learning activities.

Field observations were carried out by conducting pre-research at SMA Negeri 13 Surabaya with class XI IPA students. 54.3\% of students experienced difficulty understanding the learning process in covalent bonding. It causes the materials in chemical bonds are abstract materials that are difficult to learn contextually (Safitri, 2018).

\section{c. Task Analysis}

This analysis aims to determine the skills to be studied in the research. Task analysis is carried out by compiling the content design of teaching materials, 3D objects, augmented reality technology that will be used. This material was adjusted appropriately with the curriculum at SMAN 13 Surabaya, namely the 2013 revised curriculum.

\section{d. Material Analysis}

This analysis aims to identify materials that will be contained and contained in teaching materials. The material adjusts with basic competencies of 3.5 and 4.5, comparing ionic, covalent, and metal bonds and their properties.

\section{e. Specifying Instructional Objective}

Learning objectives are formulated as a basis to prepare the media that will be developed. Covalent bond was chosen to include in teaching materials based on augmented reality technology cause the materials in the material are possible to learn through 3D objects animated illustrations.

Augmented reality can be used to fix the difficulty in understanding abstract chemistry materials that occurs cause students cannot directly witness the materials of material, such as the process of chemical bonding. (Ilyasa, 2020).

\section{Design Phase}

The design phase of teaching materials is carried out by making storyboards, preparing teaching materials and android applications, and integrate them with augmented reality technology. The application can be operated on each student's android device.

The learning process is online with a blended learning model using a Zoom platform and Whatsapp. With this model, the learning process can be combined from physical and virtual sources according to agreed conditions. (Sandi, 2012). This the display of the teaching materials that developed: 


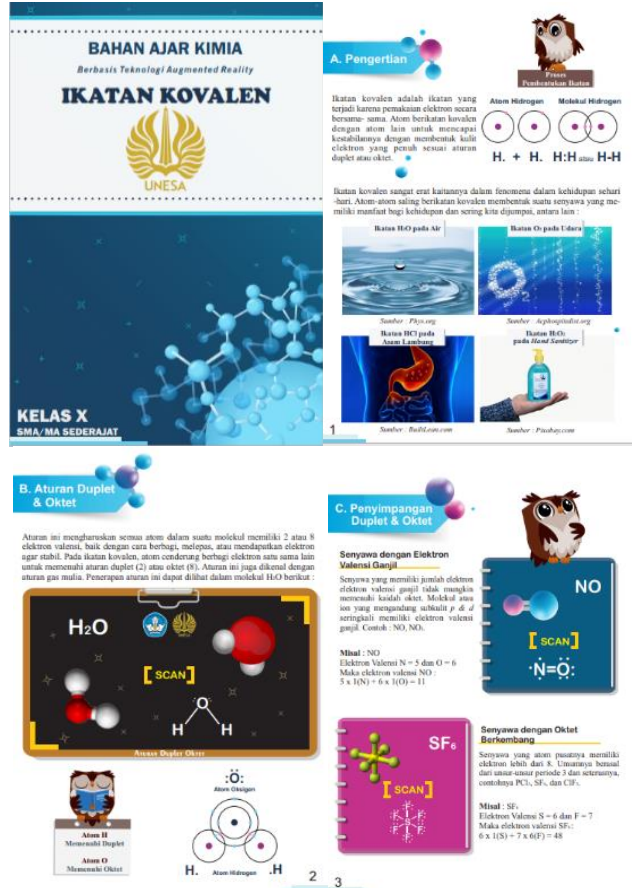

Picture 2. Learning Material Interface

Chemistry teaching materials contain the guidelines to use the teaching materials, covalent bond learning materials, and markers that have been integrated with the "AR CHEM" application that integrate by augmented reality technology. This the interface of the "AR CHEM" application that has developed:

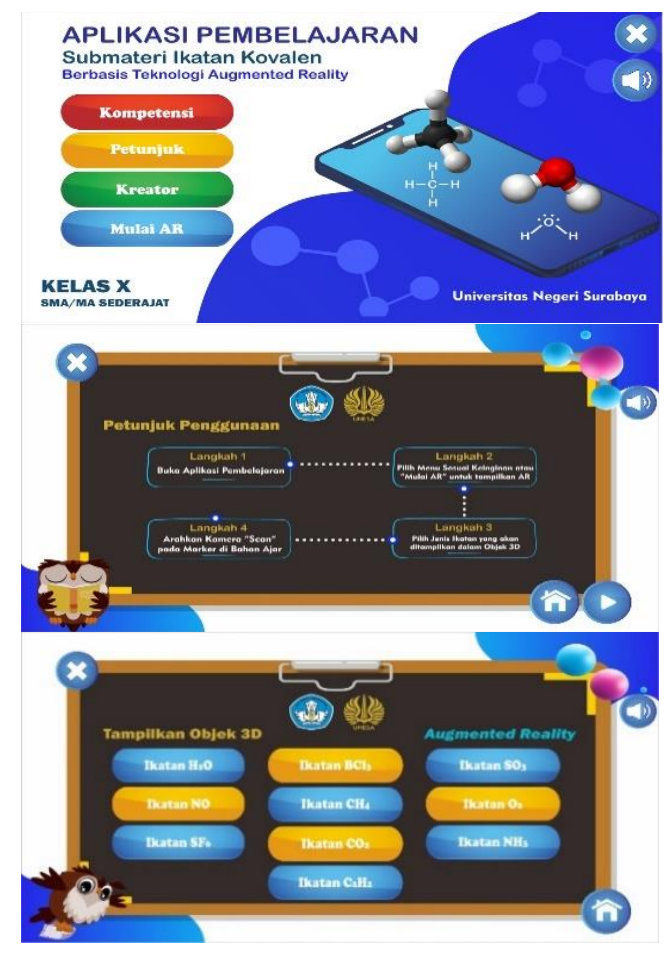

Picture 3. Application Interface

AR CHEM application contains user guidelines, learning objectives, developer information, and three 3D view menu of chemical bonding material objects with augmented reality. The 3D object view displayed :

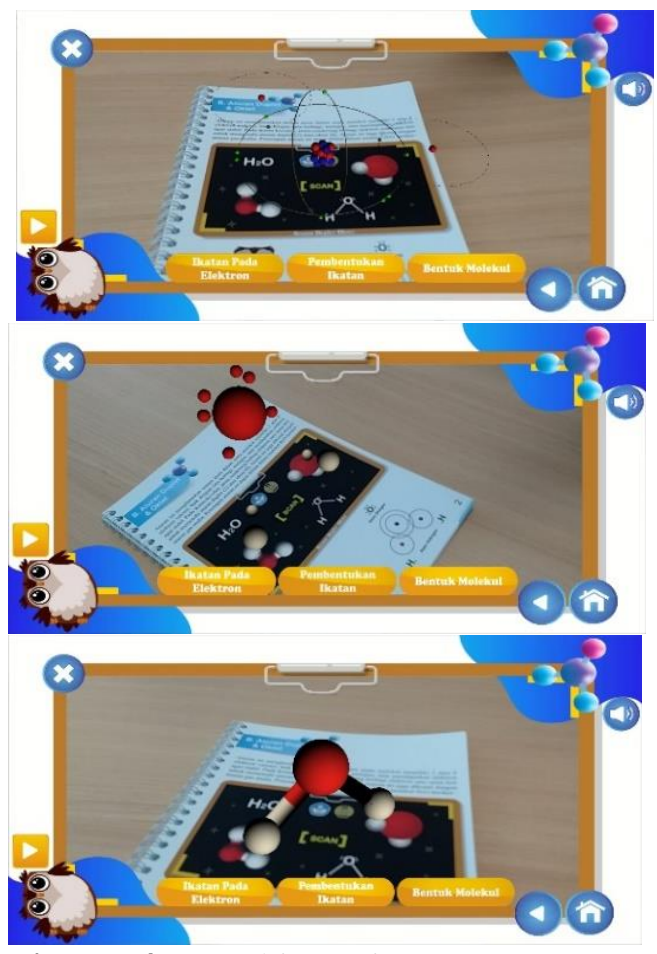

Picture 4. 3D Object View

The complete files of media can access from this link: http://bit.ly/BahanAjarAR

\section{Develop Phase}

The development phase was carried out to get valid devices through a validation process by two chemistry lecturers and one chemistry teacher before being tested to obtain practicality and effectiveness data. The phase includes:

\section{a. Validation Phase}

Teaching materials that were developed were validated by two lecturers of the chemistry department, faculty of mathematics and natural sciences Unesa, and one chemistry teacher at SMAN 13 Surabaya, then get some revisions before tested. The validation results developed are adjusted according to Plomp and Nieven (2010), validation consists of the validity of content and construct.

\section{b. Revision Phase}

Based on the validation results in draft I, the teaching material was then revised to produce draft II. This the result of media validity that developed :

Table 7. Validation Result 


\begin{tabular}{|c|c|c|}
\hline No. & Aspects Assessed & $\begin{array}{l}\text { Percentage } \\
\text { \& Criteria }\end{array}$ \\
\hline \multirow[t]{4}{*}{1.} & Content Validity & \\
\hline & Material accuracy & $\begin{array}{c}82,85 \% \\
\text { (Very Valid) }\end{array}$ \\
\hline & Skill practice & $\begin{array}{c}82,22 \% \\
\text { (Very Valid) }\end{array}$ \\
\hline & Average & $\begin{array}{c}82,66 \% \\
\text { (Very Valid) }\end{array}$ \\
\hline \multirow[t]{8}{*}{2.} & Construct Validity & \\
\hline & Chemical characteristic & $\begin{array}{l}80 \% \\
\text { (Valid) }\end{array}$ \\
\hline & $\begin{array}{l}\text { Suitability with student } \\
\text { characteristics }\end{array}$ & $\begin{array}{c}93,33 \% \\
\text { (Very Valid) }\end{array}$ \\
\hline & Guiding instructions & $\begin{array}{l}80 \% \\
\text { (Valid) }\end{array}$ \\
\hline & Media interface & $\begin{array}{c}88,88 \% \\
\text { (Very Valid) }\end{array}$ \\
\hline & Audio \& sound effect & $\begin{array}{c}93,33 \% \\
\text { (Very Valid) }\end{array}$ \\
\hline & Language validity & $\begin{array}{c}80 \% \\
\text { (Valid) }\end{array}$ \\
\hline & Average & $\begin{array}{c}85,55 \% \\
\text { (Very Valid) }\end{array}$ \\
\hline
\end{tabular}

Based on Table 7, each aspect of validation can be valid because the average of content and construct aspect sequentially get $82,66 \%$ and $85,55 \%$ in a very valid category in the range of $80 \%-100 \%$. Based on these criteria, the development of teaching materials in this study is considered feasible in terms of validity because the percentage criteria $\geq 61 \%$.

The content validity shows that the covalent bonding materials and skill practice used is valid and according to the 2013 curriculum. The content validity gets a percentage of $82.66 \%$ that can be said is a very valid category. It is important because a good understanding of the materials given will make it easier for students to understand chemical bonding material (Widarti et al., 2018).

The construct validity consists of seven aspects that each aspect has been stated in the category of valid to very valid in the percentage range of $80 \%-100 \%$ with an average of $85.55 \%$ in the very valid category. This validity contains an assessment of the presentation, graphic, and linguistic results of the teaching materials developed.

The advantages of the media developed, teaching materials has integrated with augmented reality technology. It makes the learning process more interactive, and learners can understand the material of covalent bonds that are abstract. It is expected to help learners understand abstract materials into the concrete at the submicroscopic level (Nopihargu, 2014).

\section{c. Limited Trial Phase}

The limited trial was conducted limited to 20 students of class XI IPA at SMAN 13 Surabaya online with a blended learning model using the zoom platform and Whatsapp. The limited trial was conducted to obtain practical data from students' responses and observations and the effectiveness of learning outcomes and student motivation.

\section{1) Media Practical}

The practicality of the media is obtained after online learning using the developed media. The practicality results developed according to Plomp and Nieven (2010), practice conduct by practical of content and construct. The actual implementation to get practical data by the usable of media that has been designed and developed. The following is the data on the response of students in Table 8.

Table 8. Student Response Result

\begin{tabular}{llc}
\hline No & Aspects Assessed & $\begin{array}{c}\text { Percentage \& } \\
\text { Criteria }\end{array}$ \\
\hline 1. & $\begin{array}{l}\text { Convenience to } \\
\text { operating } \\
\text { application }\end{array}$ & $\begin{array}{c}92,5 \% \\
\text { (Very Practical) }\end{array}$ \\
\hline 2. & Clarity of language & $\begin{array}{c}98,33 \% \\
\text { (Very Practical) }\end{array}$ \\
\hline 3. & $\begin{array}{l}\text { Teaching material } \\
\text { benefit }\end{array}$ & $\begin{array}{c}95 \% \\
\text { (Very Practical) }\end{array}$ \\
\hline 4. & $\begin{array}{l}\text { Teaching material } \\
\text { interest based on } \\
\text { augmented reality }\end{array}$ & $\begin{array}{c}95 \% \\
\text { (Very Practical) }\end{array}$ \\
\hline & Average & $\begin{array}{c}95,5 \% \\
\text { (Very Practical) }\end{array}$ \\
\hline
\end{tabular}

Based on Table 7, it can be seen that the results of the response of students in each aspect obtained a percentage of $80 \%-100 \%$ with an average of $95.5 \%$ in the very practical category. So, this teaching material based on augmented reality can be declared practical in terms of the students' responses. 
The results of the students' responses are important to find out the strengths or weaknesses in the development of this teaching material. Based on the students' interest, augmented reality technology is something new in learning. Due to the use of technology like augmented reality that is integrated with learning media will provide meaningful learning and attract students' attention by following the learning process (Sirakaya and Cakmak, 2018).

In addition, the responses of students after getting learning, the results of observations by observers to students during the learning process take place. The limited trial was conducted twice with three observers at the second meeting. The following is the observation data of students in Table 9.

Table 9. Student Observation Result

\begin{tabular}{llc}
\hline No & Aspects Observed & $\begin{array}{c}\text { Percentage } \\
\text { \& Criteria }\end{array}$ \\
\hline 1. & $\begin{array}{l}\text { Students haven't trouble } \\
\text { to install applications on } \\
\text { android devices. }\end{array}$ & $\begin{array}{c}\text { 91,66\% } \\
\text { (Very }\end{array}$ \\
\hline Practical)
\end{tabular}

\begin{tabular}{clc}
\hline 9. & $\begin{array}{l}\text { Students can use } \\
\text { teaching materials easily }\end{array}$ & $\begin{array}{c}100 \% \\
\text { (Very } \\
\text { Practical) }\end{array}$ \\
\hline 10. & $\begin{array}{l}\text { Students understand the } \\
\text { procedure using teaching } \\
\text { materials based on } \\
\text { Augmented Reality }\end{array}$ & $\begin{array}{c}100 \% \\
\text { (Very } \\
\text { Practical) }\end{array}$ \\
\hline 11. & $\begin{array}{l}\text { Students can clearly read } \\
\text { the information } \\
\text { contained in the teaching } \\
\text { materials }\end{array}$ & $\begin{array}{c}100 \% \\
\text { (Very } \\
\text { Practical) }\end{array}$ \\
\hline 12. & $\begin{array}{l}\text { Students are enthusiastic } \\
\text { in the learning process } \\
\text { using teaching material }\end{array}$ & $\begin{array}{c}100 \% \\
\text { (Very }\end{array}$ \\
& \multicolumn{1}{c}{ Practical) } \\
& \multicolumn{1}{c}{ Average } & (Very \\
& & Practical)
\end{tabular}

Based on Table 8, it is known that the results of student observations during the learning process using augmented reality-based teaching materials are gained an average of $98,61 \%$ with the very practical category. Based on these criteria, the development of teaching materials in this study was considered feasible in terms of practicality because the percentage criteria were $\geq 61 \%$.

\section{2) Media Effectiveness}

Teaching materials' effectiveness was obtained from limited trials of students in the online learning process using developed teaching materials to obtain learning outcome data. The effectiveness of a learning media can be measured through the learning outcomes of students.

Learning outcomes are obtained with the one group pretest-postest design system with the following learning outcomes :

Table 10. Students Learning Outcomes

\begin{tabular}{ccc}
\hline & $\begin{array}{c}\text { Medium } \\
\text { Category }\end{array}$ & $\begin{array}{c}\text { High } \\
\text { Category }\end{array}$ \\
\hline $\begin{array}{c}\text { N-Gain } \\
\text { Average }\end{array}$ & 0,6005 & 0,903 \\
\hline Students & 10 & 10 \\
\hline
\end{tabular}

Based on Table 10, it is known that the increase in student learning outcomes is analyzed using n-gain. Based on the pretest results before the use of teaching materials, $100 \%$ of the students were incomplete in understanding 
covalent bonding sub materials with an average of $45,5 \%$. It can be seen from the value $\geq 75$ in accordance with the minimum completeness value. The result of the posttest of $85 \%$ of students has completed the test with a significant increase of all students' scores, with an average of $85,5 \%$.

Then, reanalyzed the data from the pretest and posttest results is done using the normality test and paired sample t-test with the IBM SPSS Statistics 23 software with a significant level of $5 \%$ in the Shapiro-Wilk analysis normally test. The results of the normality test obtained data in Table 11 .

Table 11. Normality Test Shapiro-Wilk

\begin{tabular}{lccc}
\hline \multicolumn{4}{c}{ Shapiro-Wilk } \\
\hline & Statistic & Df & Sig \\
\hline Pretest &, 916 & 20 &, 083 \\
\hline Postest &, 864 & 20 &, 009 \\
\hline
\end{tabular}

Based on Table 11, it is obtained that the data is normally distributed based on the significant pretest value of 0,083 and the posttest value of 0,009 . The value is $>0.05$ so that a paired sample t-test can be done with a significant level of 5\%. The test results can be seen in Table 12.

Table 12. Result of Paired Sample t-Test

\begin{tabular}{lccc}
\hline & $\mathbf{t}$ & Df & $\begin{array}{c}\text { Sig. (2- } \\
\text { tailed) }\end{array}$ \\
\hline $\begin{array}{l}\text { Pair 1 } \\
\begin{array}{l}\text { Pretest }- \\
\text { postest }\end{array}\end{array}$ & $-13,37$ & 19 &, 000 \\
\hline
\end{tabular}

Based on Table 12, the significant value is 0,000. Based on the analysis method, then $\mathrm{H}_{0}$ (There is no significant difference between the mean pretest and posttest scores) is rejected because significant $<0.05$ and $\mathrm{H}_{1}$ (There is a significant difference. between the mean pretest and posttest scores) are acceptable so that the media based on augmented reality teaching materials can be declared effective in terms of the learning outcomes of students. According to Kamelia (2015), augmented reality gives virtual object interactions that appear in the real world. The combination of the virtual and real-world can make the learning process more effective and efficient.
In addition to learning outcomes, the effectiveness is also measured from students' motivation questionnaires after implementing learning using teaching materials. Following are the results of obtaining student motivation data in Table 13.

Table 13. Student Motivation Level

\begin{tabular}{clc}
\hline No & Aspects Assessed & $\begin{array}{c}\text { Percentage \& } \\
\text { Criteria }\end{array}$ \\
\hline 1. & Self Confidence & $\begin{array}{c}75,8 \% \\
\text { (Effective) }\end{array}$ \\
\hline 2. & Attention & $\begin{array}{c}82,5 \% \\
\text { (Very Effective) }\end{array}$ \\
\hline 3. & Relevance & $\begin{array}{c}80 \% \\
\text { (Effective) }\end{array}$ \\
\hline 4. & Satisfaction & $\begin{array}{c}80,34 \% \\
\text { (Vey Effective) }\end{array}$ \\
\hline & Average & 79,34 \\
& (Effective) \\
\hline
\end{tabular}

Based on Table 13. the level of students' motivation in self-confidence and satisfaction obtained the effective category with a percentage of $60 \%-80 \%$. Simultaneously, the aspects of attention and satisfaction obtained the very effective category with a percentage of $80 \%$ $100 \%$. So that average of students' motivation is $79,34 \%$, and the teaching materials based on augmented reality developed can be declared effective in terms of the motivation level of students after learning because the percentage is $\geq 61 \%$. Increase student learning motivation as a whole is important, interactive and fun learning will be useful in increasing student motivation so that learning will be meaningful (Lutfi, 2013).

\section{CONCLUSION}

Based on the objectives and the results of the explanation of interactive chemical teaching materials based on augmented reality technology in covalent bonds, it can be denied that the developed teaching materials can be declared suitable for use as teaching materials in terms of obtaining validity, practicality, and effectiveness.

This media can be used by chemistry teachers in the learning process so that students can understand more than the use of augmented reality technology in abstract chemical material. In the future, augmented reality technology is expected to be used generally in chemistry lessons so that the learning process becomes more interactive and interactive. 


\section{Chemistry Education Practice, 4 (1), 2021, 58}

Rizqullah, Lutfi

\section{RESOURCES}

Andayani, Y., Junaidi, E., 2018. Hubungan Kesiapan Teknologi Informasi Dan Komunikasi (Tik) Dengan Motivasi Belajar Kimia Siswa. Chem. Educ. Pract. J. 2, 6. https://doi.org/10.29303/cep.v2i2. 1414

Effendy, 2013. Teori VSEPR, Kepolaran, dan Gaya Antar Molekul, Edisi 3, 3rd ed. Bayumedia, Malang.

Hake, R.R., 1999. Analyzing Change/Gain Scores.

Ibrahim, M., 2014. Model Pengembangan Perangkat Pembelajaran Menurut Jerold E. Kemp \& Thiagarajan. PSMS-PPs Unesa, Surabaya.

Ilyasa, D.G., 2020. Model Multimedia Interaktif Berbasis Unity Untuk Meningkatkan Hasil Belajar Ikatan Ion. J. Inov. Pendidik. Kim. 14, 2572-2584.

Kamelia, L., 2015. Perkebangan Teknologi Augmented Reality Sebagai Media Pembelajaran Interaktif Pada Mata Kuliah Kimia Dasar IX, 16.

Lutfi, A., 2013. Memotivasi Siswa Belajar Sains Dengan Menerapkan Media Pembelajaran Komik Bilingual. J. Pendidik. Dan Pembelajaran 20, 152-159.

Nopihargu, A., 2014. Implementasi Strategi Pembelajaran Intertekstual Pada Materi Reaksi Redoks Kelas X. J. Univ. Pendidik. Indones.

Plomp, T., Nieveen, N., 2010. Educational Education Research. SLO, Netherlands.

Prastowo, A., 2012. Creative Guide Creating Innovative Instructional Materials. Diva Press, Yogyakarta.

Riduwan, 2015. Dasar-Dasar Statistika. Alfabeta, Bandung.
Rifa'i, M., Listyorini, T., Latubessy, A., 2014. Penerapan Teknologi Augmented Reality Pada Aplikasi Katalog Rumah Berbasis Android. Pros. SNATIF 1, 267-24.

Sandi, G., 2012. Pengaruh Blended Learning Terhadap Hasil Belajar Kimia Ditinjau Dari Kemandirian Siswa 45, 241-251.

Sirakaya, M., Cakmak, E.K., 2018. The Effect of Augmented Reality Use on Achievement, Misconception and Course Engagement. Contemp. Educ. Technol. 9. https://doi. org/10.30935/cet.444119

Widarti, H.R., Safitri, A.F., Sukarianingsih, D., 2018. Identiikasi Pemahaman Konsep Ikatan Kimia. J-PEK J. Pembelajaran Kim. 3, 41-50. https://doi.org/10.17977/ um026v3i12018p041

Yuliono, T., Sarwanto, S., Rintayati, P., 2018. Keefektifan Media Pembelajaran Augmented Reality Terhadap Penguasaan Konsep Sistem Pencernaan Manusia. J. Pendidik. Dasar 9, 65-84. https://doi.org /10.21009/10.21009/JPD.081 